Available online at: http://proceeding.rsfpress.com/index.php/pss/index

LPPM UPN “Veteran" Yogyakarta Conference Series

Proceeding on Political and Social Science (PSS)

Volume 1 Number 1 (2020): 263-272

\title{
Strategic Family Communication On The Covid-19 Pandemy Through Heart-To-Heart Communication
}

\author{
Puji Lestari, Eko Teguh Paripurno \\ Universitas Pembangunan Nasional Veteran Yogyakarta \\ Email Address puji.lestari@upnyk.ac.id
}

\begin{abstract}
The spread of COVID-19 in Indonesia caused anxiety to families, so there was no effective family communication in the event of a disaster. This research aims to find a strategic family communication model in addressing COVID-19 through heart-to-heart communication. This research method uses descriptive qualitative with in-depth interview data collection techniques, focus group discussions, and simulation of Gending Dhandang Gula Corona. The subjects of this study were families affected by COVID-19 in Ngandong Village. The results of this study found a model of strategic family communication in dealing with COVID-19 through heart-to-heart communication. Heart-to-heart communication affects a positive spirit, the soul influences positive feelings, feelings influence positive thoughts, thoughts affect positive attitudes, and attitudes influence positive behavior. Positive behavior makes a disaster-resilient family. Disaster resilient families are developed by applying heart-to-heart communication. The contribution of this research in the form of family strategic communication models and policies in addressing COVID-19 through heart-to-heart communication.
\end{abstract}

Keywords: COVID-19; Heart-to-Heart Communication Model; Family Strategic Communication Model

\section{INTRODUCTION}

This is an open access article under the CC-BY-NC license.

At the end of 2019, Coronavirus Disease 2019 (COVID-19) first appeared in Wuhan City, China (Brown, Kumar, Rajji, Pollock, \& Mulsant, 2020). COVID-19 is a disease caused by severe acute respiratory syndrome coronavirus 2 (SARS-CoV-2) (Tang et al., 2020). The disease spread quickly and on a large scale (Hiroshi et al., 2020) to several countries, becoming a pandemic and becoming a global health emergency. One of the stricken countries is Indonesia.

In Indonesia, COVID-19 began to spread in March 2020, data as of 5 May 2020 as many as 872 people died, and 12,071 tested positive for COVID-19 (Covid19.go.id, 2020). COVID19 is mostly spread through close contact within a community (Tang et al., 2020) so that the spread of COVID-19 began to threaten the smallest social unit, namely the family cluster 
(Kaddi, Lestari, \& Adrian, 2020). The family cluster is an indication of transmission because one of the families can start with the journey of one of the family members out of the city which becomes the transmission area of COVID-19 transmission. This leads to contagion to the family members and other families.

The family becomes a very vulnerable place because the family is the first place a group of people who are bound in marriage, commitment, or blood legally or illegally to maintain the culture, create, and improving physical, mental, emotional development share future expectations regarding related relationships (Bala, Senduk, \& Boham, 2015). This interconnected family relationship is continuous and intimate, so that among the family members who experience certain events then other family members feel the event. One family member who felt anxiety in the face of the COVID-19 disaster, then other family members also felt that. These feelings should not be nurtured, so one of the family members must heal his family's heart and mind. This made the family united and said to be a successful family in the fight against disaster. The success of a unified family and adjusting to each other's families depends heavily on how they communicate between families (Nurhajati \& Wardyaningrum, 2014).

Family communication is communication that exists between parents and children, or between husband and wife in various ways as a means of exchanging information, thoughts, socializing the personality values of parents to their children, and conveying all problems that occur and complaints of children to parents (Santi, Koagouw, \& Mingkid, 2015). Family communication in the face of the COVID-19 disaster requires good communication planning in order for communication to be established smoothly between families. Communication planning is a way used within the family to properly disseminate positive information between families from parent to child and child to parent through appropriate channels and timely places (Wijaya, 2015). This is what is used for the creation of strategic communication.

Strategic communication is communication that is entirely consistent with the organization's vision, mission, and values and is able to enhance strategic 'positioning' and competitiveness with other organizations (Hardjana, 2017). This strategic communication aims to improve the vision of a disaster-resilient family by realizing the mission. The family is the first place for the growth and development of children both physically and spiritually (Wahidin, 2017) so that parents need to instill a good and positive influence on the child in dealing with problems such as fostering disaster resilience from within.

Research on family strategic communication was conducted by Sofian (2014) which states that communicating interactively and conductively makes families harmonious and fosters warmth and intimacy. The difference with this research is the strategic communication of families in responding to the COVID-19 disaster through heart-to-heart communication. This research also applies the local wisdom of Gending Dhandhang Gula Corona as a message so that families do not feel anxious and anxious about COVID-19. This study aims to find a family strategic communication model in responding to COVID-19 through heartto-heart communication. 


\section{LITERATURE REVIEW}

This research uses the concept of strategic communication. Strategic communication is the best combination of all communication elements ranging from communicators, messages, channels (media), receivers to influences (effects) designed to achieve optimal goals (Putri \& Rosilawati, 2020). In this study, the communicator is the creator of gending and pengrawit, a message in the form of Gending Dhandang Gula Corona, a medium used in the form of gamelan and wirasuara. The recipient of the message is family in Bometen Village, Ngandong Village, Gantiwarno, Klaten. Researchers have conducted strategic communication, namely strategic communication for earthquake disasters in Bantul using Javanese cultural values, namely: (1) religion-spiritual values; (2) moral values; (3) societal values; (4) the value of leadership and governance; (5) the value of the joy and the brotherly; (6) the value of the typical spirit of keyogyakartaan (Lestari, Puji., DN, RR Susilastuti., Hendariningrum, 2009).

The author also examines the communication strategy of the Karo Regional Government in overcoming communication problems between the government and the victims of Mount Sinabung through the SMS Gateway (Lestari, P., Paripurno, E. T., Wijoyono, E., Suntoro, I., \& Brata, 2014). Besides, the author has also researched Sinabung disaster communication strategies through local wisdom, namely: 1). Karo language; (2) Jambur; (3) Philosophy, (4) ecology; (5) kinship or kinship system; (6) kerja tahun (Lestari \& Paripurno, 2015).

The study also used local wisdom theory. Local wisdom is a reference for behaving in a community. Local wisdom is local cultural values in the form of community activities that can be used as a system of life control and answer the problems faced (Fajarini, 2014). Local wisdom can be found in the singing, proverbs, admonitions, mottos, and ancient books inherent in the behavior of daily life. Local wisdom is reflected in people's long-standing living habits and in its development transforms into traditions, although the process takes a very long time (Haryanto, 2014). Local wisdom used in this study is the habit of people who sing Gending to pour out the heart, namely through Gending Dhandhang Gula Corona. Researchers have researched local wisdom, namely local wisdom gending Java to formulate a model of crisis communication impact from COVID-19 (Lestari \& Sularso, 2020). The study stated that local wisdom gending Java is useful to prevent COVID-19 and provide a positive message for people to stay at home, maintain health, and improve the immune system. Other local wisdom researched by is local wisdom that is used to avoid throwing mistakes at each other, throwing responsibility when there is a disaster even to overcome the conflict due to disaster, namely through purpose in Karo Regency, North Sumatra (Lestari, Kertamukti, \& Ruliana, 2019).

\section{RESEARCH METHODOLOGY}

This study uses qualitative descriptive methods. Research objects in the form of strategic family communication. The subjects of this study were families affected by COVID-19 in Ngandong Village, Gantiwarno Sub-District, Klaten. Data collection method using in-depth interviews, Focus Group Discussion (FGD), and simulation of Gending Dhandang Gula 
Corona. FGD participants and simulations, namely: 10 families affected by COVID-19. The research was conducted in July in Ngandong Village, Gantiwarno Sub-district.

The data analysis technique alliteratively refers to Ali (Ali, 2015) conducted with: (1) data collection during pre-research, moment-of-research, and post-research. Data collected related to COVID-19 disaster communication before simulation, during simulation, and after COVID-19 disaster management simulation; (2) the presentation of the data is done by selecting the necessary data and relevant to the research, then presenting it in the form of a table or image; (3) draw conclusions on the data that has been presented into the interpretation of results of the research. Withdrawal of conclusions related to the new findings of COVID-19 disaster communication through heart-to-heart communication.

\section{FINDING AND DISCUSSION}

The results found information related to the COVID-19 disaster communication model through liver-to-heart communication. Researchers conducted interviews with families in Ngandong Village who felt anxiety in the face of the COVID-19 disaster. One of the families stated that:

"The role of the family is really being tested during this time of COVID-19. The problem is I am also worried when the outbreak will end so that I can work outside the home, do other activities, not at home. Now I have been at home for almost 6 months, my needs must be fulfilled plus vitamins, I am increasingly worried about whether for the next few months, whether I will be able to support my family. I am also worried that when I come home shopping from the shop, am I still healthy or what. Fear that later it will bring the virus into the family. I worry too much, so my thoughts are negative about COVID-19. Hopefully, this COVID-19 will pass quickly, okay?"(ARB Family, 19 September 2020).

Anxiety is felt by the ARB family due to the COVID-19 pandemic, anxious about the spread of COVID-19 in the family cluster. This feeling of anxiety arises because of the individual's lack of closeness to the Creator of the Universe. Every family hopes that COVID-19 will end quickly and not cause excessive anxiety. This is following the lyrics of Gending Dhandhang Gula Corona written by researchers about hope for the Creator so that COVID19 disappears quickly (Fig. 1). 


$\begin{array}{ll} & \begin{array}{c}\text { Dhandhang Gula Corona } \\ \text { Cipt. Puji Lestari dan Sri Rejeki } \\ \text { Wirasuara: Sanggar Rasa Jati }\end{array} \\ & \\ \text { Mangga samya, manekung mring Gusti } & \text { Covid sangalas kang nggegirisi } \\ \text { Ojo Lali, kang padha manembah } & \text { Mugi enggal oncat saking jagat } \\ \text { Nyuwun ngapuro dosane } & \text { Kang sampun kathah kurbane } \\ \text { Dimen tansah rahayu } & \text { Dhuh Gusti kang ma Luhur } \\ \text { Mugi tinebihno sesakit } & \text { Mugi tansah paring Aksami } \\ \text { Nggegiris Corona } & \text { Ugi paringa berkah } \\ \text { Muga enggal mlayu } & \text { Sadaya Rahayu } \\ \text { Padha njaga kasarasan } & \text { Mangga samia waspada } \\ \text { Tansah ngudi reresik diri pribadi } & \text { Kasarasan iku kang tansah kaesthi } \\ \text { Allah kang paring berkah } & \text { Kalis saking bebaya }\end{array}$

Figure. 1 Lyrics of the song Dhandhang Gula Corona

Source: Documentation of Gending Creators (Puji Lestari and Sri Rejeki, 2020)

The meaning of the song in Fig. 1 is to invite all to bow down to God and don't forget to worship Allah. We apologize for all sins so that each individual will remain blessed, kept away from the disease, and the dangers of COVID-19. Gending Dhandhang Gula Corona means hope in God Almighty to give forgiveness to His people, give blessings, give salvation. Another hope is that the COVID-19 will soon disappear from the earth because there have been many victims. The song also reminded all people to make efforts to clean themselves, increase awareness, and maintain health because health is the main thing, and is safe from the dangers of the COVID-19.

The LDS family states that:

"Honestly, after I listened to this Gendhing, I was moved. I was reminded again to stay close to God, maybe at this time we humans are being tested. I sometimes just complain, work, and complain because I have little income and limited work. I should be more grateful and get closer to God so that my mind is clear and I am given health and kept away from various diseases. This piece also gives another positive message for me to stay alert and maintain personal hygiene "(LDS Family, 19 September 2020).

Based on the results of interviews from several of these families, families in Ngandong Village often complain and forget to always get closer to the Creator. Positive thoughts are confused by an anxious heart. This is supported by the circumstances that must be faced by the family and society, namely being vigilant in everything to avoid danger. The local wisdom of Gendhing Jawa Dhandhang Gulo Corona has a positive impact on listeners in Ngandong Village who are used to singing Javanese Gendhing. This is following the local wisdom theory which explains that the community or family life habits have been going on for a long time (Haryanto, 2014). Families must continue to heed positive thoughts and hearts to stay healthy and resilient to fight the COVID-19 disaster. 


\section{IV.1. Heart Communication in Addressing Family Problems due to COVID-19}

One of the results of the Forum Group Discussion (FGD) states that the social impacts that arise are not being able to have direct contact with relatives, friends, relatives, the community, the environment, including to places of worship. The economic impact in the family is felt, namely, the income is reduced even though there are more daily needs that must be fulfilled because it must also support health or immune problems. The psychological impact that is felt in the family is the feeling of anxiety, fear, worry, stress, boredom, and emotions.

Prevention of COVID-19 in the family is made successful by having strategic communication so that it runs smoothly. This is in accordance with the concept of strategic communication, namely all forms of activities designed and delivered to achieve the desired results by making effective interactions and applying all communication elements (Naryoso, 2014). In this case, the elements of communication start from 1) the communicator, namely the composer of the music and the composer of the Gending; 2) the message delivered was in the form of Gending Dhandang Gula Corona; 3) the channels used in the delivery of messages are gamelan and wirasuara from Sanggar Rasa Jati; and 4) the recipient of the message is a family in Dusun Bometen, Kelurahan Ngandong, Gantiwarno, Klaten.

In addition, the prevention of COVID-19 by consuming healthy food, self-isolation, and reducing community gatherings (Law, Leung, \& Xu, 2020). This is supported by research conducted by Listautin \& Nurzia (2020) regarding communication strategies and health cadres services for the prevention of infectious diseases in the tribal community of children in the Batanghari Regency, Jambi Province. The results of this study indicate that there is an effect of communication strategies and health care services on the prevention of infectious diseases in tribal children in Batanghari Regency, Jambi Province. Strategic communication between humans must be planned, organized, and developed so that it becomes higher quality communication. The communication strategy greatly determines the extent to which the community gathers all strengths and resources for communication.

Solutions taken to overcome social impacts in the family include following the protocol from the government to stay at home if there is no urgent need, establishing communication via telephone, or social media such as WhatsApp, Facebook, and Instagram. Spreading positive things on social media carry out this communication, by channeling heart-to-heart communication so that there is a feeling of trust that staying at home is in reducing the spread of COVID-19. Other solutions carried out within the family, among others, are by saving money and making a priority scale in the use of funds. This can be communicated from heart to heart so that all family members can understand and understand for the welfare of the family. The solution in the family is to seek entertainment with various alternative activities such as caring for plants, sports, singing, cooking, making positive messages, and calming the mind by praying and spiritual activities with the family. Heart-to-heart communication made to God gives peace to the minds and hearts of His people.

This study produces a strategic family communication model in responding to COVID-19 through heart-to-heart communication (Fig. 2). 


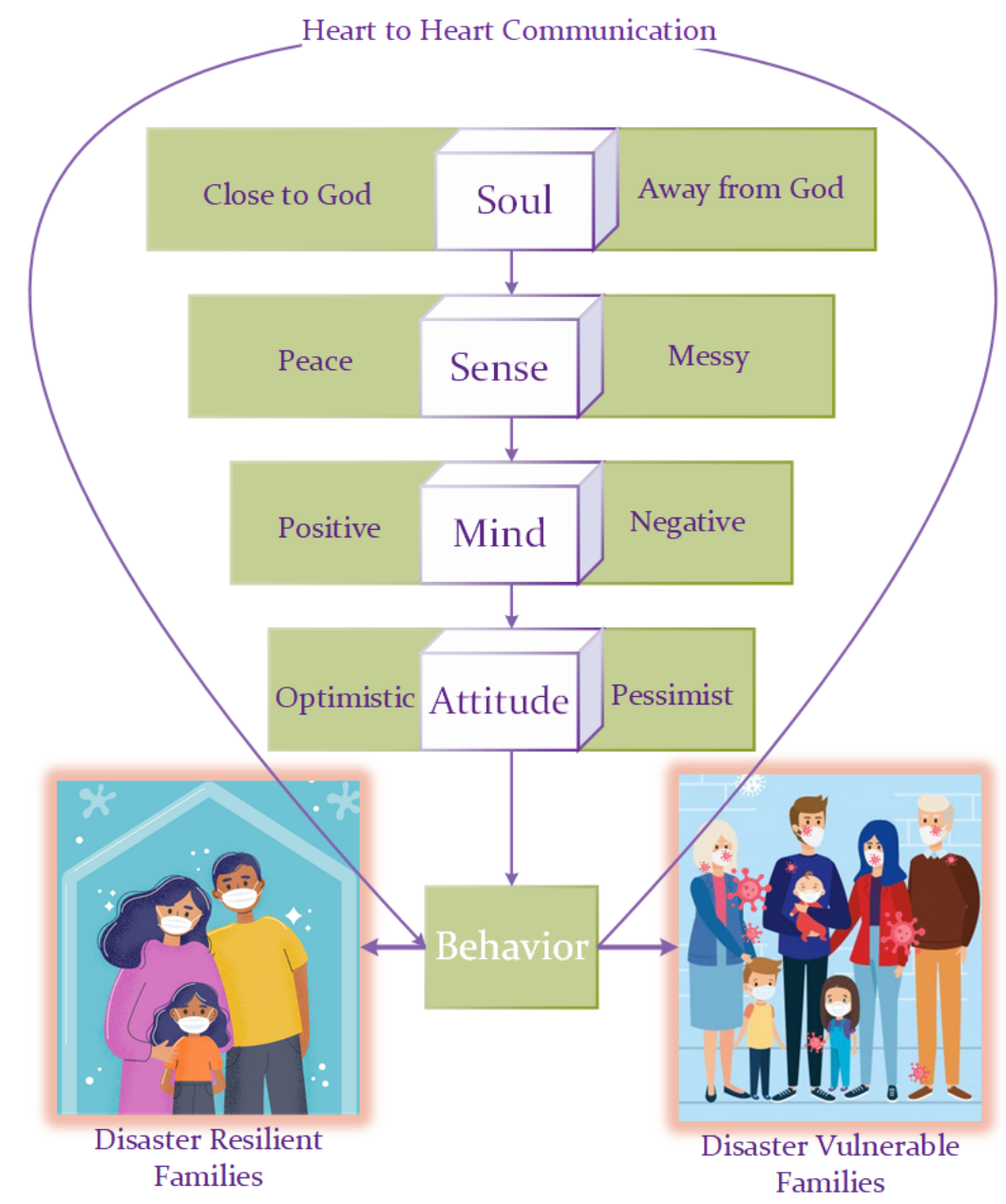

Figure. 2 Family Strategic Communication Models in Responding to COVID-19 through Heart-to-Heart Communication

Source: Researcher's analysis results (2020)

Figure 1 explains that in a COVID-19 disaster situation, an individual's closeness to God also determines the individual's attitude and behavior in dealing with disasters. Survivors who feel panic and anxious, then not accompanied by a belief in God causes people to become weak and helpless in facing various problems related to disaster crises. On the other hand, when an individual is intrapersonal to God, his soul creates a positive aura in the form of strength to face various problems he experiences. The belief that there is always a positive side to all human events results in positive thoughts. Positive thoughts give birth to positive attitudes and behaviors. The stronger the family is united with each other, the more resilient the family is in facing various disasters that occur. Resilience to disasters is fostered by family communication that supports each other in existing circumstances. Families cultivate strong beliefs in the face of the COVID-19 outbreak. Confidence is instilled by developing heart-to-heart communication between families. 


\section{CONCLUSION AND FURTHER RESEARCH}

The family communication strategy in responding to the COVID-19 pandemic can be done by heart-to-heart communication regarding various activities in the family. Heart-to-heart communication can be implemented starting from creating positive thoughts and feelings facing COVID-19. Positive thoughts encourage positive attitudes and behaviors in daily activities at home. Positive attitudes and behaviors can be co-created with mutual support, being guided and monitored by parents. Positive activities and in accordance with government protocols make families ready to be safe and resilient to the COVID-19 disaster. The contribution of this research is in the form of recommendations for strategic family communication models in responding to residents of COVID-19 through heart-toheart communication.

\section{REFERENCES}

Ali, U. (2015). Teknik Pengumpulan dan Analisis Data Kualitatif. Diambil 10 Januari 2019, dari http://www.pengertianpakar.com/2015/05/teknik-pengumpulan-dan-analisis-datakualitatif.html

Bala, M. E., Senduk, J., \& Boham, A. (2015). Peran Komunikasi Keluarga dalam Mencegah Perilaku Merokok bagi Remaja di Kelurahan Winangun Kecamatan Malalayang Kota Manado. Jurnal Acta Diurna, IV(3), 1-11. Diambil dari http://ejournal.unsrat.ac.id/index.php/actadiurna/article/viewFile/7498/7045

Brown, E. E., Kumar, S., Rajji, T. K., Pollock, B. G., \& Mulsant, B. H. (2020). Anticipating and Mitigating the Impact of COVID-19 Pandemic on Alzheimer's Disease and Related Dementias. The American Journal of Geriatric Psychiatry, 1-10. https://doi.org/10.1016/j.jagp.2020.04.010

Covid19.go.id. (2020). COVID-19.

Fajarini, U. (2014). Peranan Kearifan Lokal Dalam Pendidikan Karakter. SOSIO DIDAKTIKA: Social Science Education Journal, 1(2). https://doi.org/10.15408/sd.v1i2.1225

Hardjana, A. (2017). Komunikasi Strategis: Konsep \& Pendekatan. JURNAL HUMAS INDONESIA, $\quad 1(2), \quad 1-12 . \quad$ Diambil dari https://jpri.perhumas.or.id/ojs/index.php/jpri/article/view/18

Haryanto, J. T. (2014). Kearifan Lokal Pendukung Kerukunan Beragama pada Komuntias Tengger Malang Jatim. Analisa: Journal of Social Science and Religion, 21(2), 201-213. https://doi.org/10.18784/analisa.v21i02.15

Hiroshi, N., Oshitani, H., Kobayashi, T., Saito, T., Sunagawa, T., Matsui, T., ... Suzuki, M. (2020). Closed environments facilitate the secondary transmission of coronavirus disease 2019 (COVID-19). medRxiv, 1-5. https://doi.org/https://doi.org/10.1101/2020.02.28.20029272

Kaddi, S. M., Lestari, P., \& Adrian, D. (2020). Komunikasi Keluarga Dalam Pencegahan Coronavirus Disease 2019. Jurnal Ilmu Komunikasi, 18(1), 63-74. https://doi.org/10.31315/jik.v18i1.3701

Law, S., Leung, A. W., \& Xu, C. (2020). Severe Acute Respiratory Syndrome (SARS) and Coronavirus disease-2019 (COVID-19): From Causes to Preventions in Hong Kong. 
International Journal of Infectious Diseases, 94, 156-163. https://doi.org/10.1016/j.ijid.2020.03.059

Lestari, P., Paripurno, E. T., Wijoyono, E., Suntoro, I., \& Brata, G. K. (2014). Communication Model for Disaster Risk Reduction with SMS Gateway and SOP for Early Warning Communications of Mount Sinabung in Indonesia. In The 5th International Conference on Sustainable Future Sustain for Human Security (hal. 172183). diambil dari http://sustain-conference.com/files/procs/Proceeding SustaiN 2014.pdf

Lestari, Puji., DN, RR Susilastuti., Hendariningrum, R. (2009). Manajemen Konflik Berbasis Budaya Lokal Sebagai Upaya Meningkatkan Jati Diri Bangsa Indonesia. Journal Ikatan Sarjana Komunikasi Indonesia, I(1), 73-96. Diambil dari http://eprints.upnyk.ac.id/14663/

Lestari, P., Kertamukti, R., \& Ruliana, P. (2019). Use of Local Wisdom (Purpusage) through Heart-to-Heart Communication in Settling of Social Conflicts in Karo, North Sumatra Indonesia. Jurnal Komunikasi: Malaysian Journal of Communication, 35(3), 163-181. https://doi.org/doi.org/10.17576/JKMJC-2019-3503-10

Lestari, P., \& Paripurno, E. T. (2015). LOCAL WISDOM AS ALTERNATIVE OF DISASTER COMMUNICATION MANAGEMENT IN MOUNT SINABUNG, KARO REGENCY, NORTH SUMATERA, INDONESIA. The Indonesian Journal of Communication Studies (IJCS), 08(1), 128-142. diambil dari http://jurnal.upnyk.ac.id/index.php/ijcs/article/view/2976

Lestari, P., \& Sularso. (2020). The COVID-19 impact crisis communication model using gending Jawa local wisdom. International Journal of Communication and Society, 2(1), 47-57. https://doi.org/doi.org/10.31763/ijcs.v2i1.150

Listautin, L., \& Nurzia, N. (2020). Strategi Komunikasi dan Pelayanan Kader Kesehatan terhadap Pencegahan Penyakit Menular pada Komunitas Suku Anak dalam di Kabupaten Batanghari Provinsi Jambi. Jurnal Ilmiah Universitas Batanghari Jambi, 20(1), 21-25. https://doi.org/10.33087/jiubj.v20i1.795

Naryoso, A. (2014). Model Komunikasi Strategis untuk Mengatasi Teror HIV pada Kelompok Pekerja Seks Komersial (PSK) Bandungan. Ragam, 14(3), 185-202. Diambil dari https://jurnal.polines.ac.id/index.php/ragam/article/view/510

Nurhajati, L., \& Wardyaningrum, D. (2014). Komunikasi Keluarga dalam Pengambilan Keputusan Perkawinan di Usia Remaja. Jurnal AL-AZHAR Indoensia Seri Pranata Sosial, 1(4), 236-248. https://doi.org/10.1109/ROBOT.1997.620145

Putri, R. A., \& Rosilawati, Y. (2020). Komunikasi Strategis Pemerintah Kota Yogyakarta dalam Mensosialisasikan Kawasan Pedestrian di Malioboro. Jurnal Audiens, 1(1), 8899. https://doi.org/10.18196/ja.11011

Santi, M. R., Koagouw, F., \& Mingkid, E. (2015). Pola komunikasi anak-anak delinkuen pada keluarga broken home di Kelurahan Karombasan Selatan Kecamatan Wanea Kota Manado. "Acta Diurna," IV(4).

Sofian, F. A. (2014). Makna Komunikasi Keluarga Bagi Wanita Karier: Studi Fenomenologi Mengenai Makna Komunikasi Keluarga Bagi Wanita Karier di Kota Bandung. Humaniora, 5(1), 468-482. https://doi.org/10.21512/humaniora.v5i1.3054 
Tang, B., Li, S., Xiong, Y., Tian, M., Yu, J., Xu, L., .. Liu, S. (2020). Coronavirus Disease 2019 (COVID-19) Pneumonia in a Hemodialysis Patient. Kidney Medicine, XX(March), 1-5. https://doi.org/10.1016/j.xkme.2020.03.001

Wahidin, U. (2017). Peran Strategis Keluarga Dalam Pendidikan Anak. Edukasi Islami : Jurnal Pendidikan Islam, 1(02), 1-9. https://doi.org/10.30868/ei.v1i02.19

Wijaya, I. S. (2015). Perencanaan dan strategi komunikasi dalam kegiatan pembangunan. Lentera, XVIII(1), 53-61. https://doi.org/https://doi.org/10.21093/lj.v17i1.428 